\title{
Issues of Price Formation for Products of the Forestry Sector
}

\author{
Tatiana Kolesnikova ${ }^{1}$, Tatiana Naumova ${ }^{1}$, Liudmila Smolennikova ${ }^{1,{ }^{*}}$, Natalia Strelnikova ${ }^{1}$ and \\ Nilufar Babahanova ${ }^{2}$ \\ ${ }^{1}$ Volga State University of Technology, 424000, Yoshkar-Ola, Russia \\ ${ }^{2}$ Tashkent State Transport University, Tashkent, Uzbekistan
}

\begin{abstract}
The article considers a theoretical framework of an enterprise's cost classification, states several types of product calculations, defines possible variants of determining a prime cost of harvesting $1 \mathrm{~m}^{3}$ of timber in the environment of the Republic of Mari El, emphasizes some regional specific features of pricing for wood resources.
\end{abstract}

\section{Introduction}

Economic and legislative transformations in Russia make a direct impact on the context of forestry functioning and the pricing policy of forestry products.

In present-day conditions, lease of forest lands has become the main form of forest use. At the same time, the management and economic functions in the forestry are separated according to the legislation. The major part of the total forest area is leased out for timber harvesting. Lease holders face problems with formation of prime cost for harvesting $1 \mathrm{~m}^{3}$ of timber. Many lease holders calculate their expenses on the base of an actual value and then distribute it on the final product with reference to profit. This method does not give any information on distribution of expenses with regard to timber species and assortment. This method may be used in case of small scale harvesting. If timber harvesting is significant, then this method will increase the probability of a harvester's operating at a loss. Therefore, an operating income mainly depends on the method of cost assignment to final products. It forms the rationale of the research.

The goal of this study is to justify a prime cost of harvesting $1 \mathrm{~m}^{3}$ of timber.

The object of the study is the market of wood resources and their reproduction process in the Republic of Mari El.

The subject of the study is the methodology and mechanism of generating payments for wood resources.

\section{Materials and methods}

The theoretical and methodological base of the study is comprised of works by foreign and Russian researchers on the issues of price formation for forestry products.

\footnotetext{
*Corresponding author: SmolennikovaLV@volgatech.net
} 


\section{Results}

Operating expenses, process costs and the prime cost of products are essential economic notions that influence the financial results and as a consequence the enterprise performance. Operating expenses refer to a monetary value of an enterprise's expenses on production and sale of products (works, services). An enterprise's costs represent a combination of human, material, financial and other resources used for a reporting period. The costs may be related to:

- manufacture, this type of costs is attributed to a prime cost of products;

- investments, this type of costs is aimed at the purchase of items of fixed assets. In this context, the former are attributed to a prime cost of the products, and the latter to the enterprise's profit (except interests on credits).

Table 1 shows the classification of an enterprise's costs.

Table 1. Enterprise cost classification.

\begin{tabular}{|c|c|c|}
\hline Criterion & Cost type & Example \\
\hline \multirow[b]{2}{*}{ Composition } & single-element & materials, depreciation \\
\hline & $\begin{array}{l}\text { multi-element } \\
\text { (combined) }\end{array}$ & shop costs \\
\hline \multirow{2}{*}{$\begin{array}{l}\text { Economic function in } \\
\text { the manufacturing } \\
\text { process }\end{array}$} & prime & $\begin{array}{c}\text { raw and source materials, fuel for } \\
\text { process purposes }\end{array}$ \\
\hline & overhead & general production expenses \\
\hline \multirow{2}{*}{$\begin{array}{l}\text { Method of attributing } \\
\text { to a prime cost }\end{array}$} & direct & $\begin{array}{l}\text { raw and source materials, fuel for } \\
\text { process purposes }\end{array}$ \\
\hline & indirect & management expenses \\
\hline \multirow{2}{*}{$\begin{array}{l}\text { Relation to the } \\
\text { production volume }\end{array}$} & permanent & leasing fees \\
\hline & variable & raw and source materials \\
\hline \multirow{6}{*}{$\begin{array}{c}\text { Relation to } \\
\text { managerial decisions }\end{array}$} & alternative (imputed) & $\begin{array}{l}\text { costs due to a refusal from timber } \\
\text { harvesting on one cutting area because } \\
\text { of utilization of another one }\end{array}$ \\
\hline & differential & $\begin{array}{c}\text { a cost value calculated as a difference } \\
\text { between two alternative types of costs } \\
\text { on utilization of a cutting area }\end{array}$ \\
\hline & sunk & $\begin{array}{l}\text { an acquisition cost of an extraction } \\
\text { tractor }\end{array}$ \\
\hline & incremental & $\begin{array}{l}\text { a decision on additional harvesting } \\
\text { volume causes an increase in } \\
\text { permanent costs (payment of an } \\
\text { overtime bonus that is calculated per } \\
\text { product unit) }\end{array}$ \\
\hline & marginal & $\begin{array}{l}\text { additional costs when another } 1 \mathrm{~m}^{3} \text { of } \\
\text { timber is harvested }\end{array}$ \\
\hline & relevant & $\begin{array}{l}\text { imputed costs that affect a managerial } \\
\text { decision }\end{array}$ \\
\hline
\end{tabular}

The method of cost management is significantly determined by an accepted cost classification. In relation to the economic elements the following may be classified:

- material costs (raw and source materials, bought-in semi-finished products and complementary articles, fuel, energy, etc.); 
- labor costs (salaries and wages accrued for employees in kind and in the monetary form, bonuses, additional payments and fringe benefits and other payments attributed to compensation of employees);

- insurance contributions (deductibles from employee compensation to a social security scheme, pension plan, and a statutory health insurance fund);

- depreciation of fixed assets;

- other costs (taxes and charges attributed to a prime cost of products, payment of credit interests, business travel expenses, business expenses, etc.)

When distributed in relation to the economic elements, the monetary costs of an enterprise are not distributed to individual types of products and other economic needs. Therefore, when this method of cost management is used, it is impossible to determine a prime cost of an product item. In practice, harvesters using this method of cost distribution for forming a price for $1 \mathrm{~m}^{3}$ of timber orientate at an industry average value of their region or district. This method incurs a great probability of loss.

Calculations using account costs help to determine costs per product item. Table 2 shows the calculation of a prime cost in the general form.

Table 2. Typical calculation of a prime cost.

\begin{tabular}{|c|c|}
\hline Account cost & Calculation method \\
\hline Raw and source materials & $\begin{array}{l}\text { using norms for consumption and prices per } \\
\text { product item }\end{array}$ \\
\hline Shipping and handling expenses & $\%$ to material prices \\
\hline Recyclable wastes & $\begin{array}{l}\text { using norms and prices for possible use (to } \\
\text { be deducted) }\end{array}$ \\
\hline $\begin{array}{l}\text { Bought-in complementary articles, semi- } \\
\text { products, and production services }\end{array}$ & $\begin{array}{l}\text { using norms for consumption and prices per } \\
\text { product item }\end{array}$ \\
\hline Fuel and energy for process purposes & $\begin{array}{l}\text { using norms for consumption and prices per } \\
\text { product item }\end{array}$ \\
\hline Basic salary of direct labor & piece wage-rates \\
\hline Additional salary of direct labor & $\%$ to a basic salary \\
\hline Deductibles for social schemes & $\%$ to a basic and additional salary \\
\hline Equipment maintenance expenses & using an estimate and standard consumption \\
\hline Pre-production and start-up expenses & using an estimate and standard consumption \\
\hline Shop costs & using an estimate and standard consumption \\
\hline SHOP PRICE & $\begin{array}{l}\text { a sum of all the account costs mentioned } \\
\text { above }\end{array}$ \\
\hline General business expenses & using an estimate and standard consumption \\
\hline MANUFACTURING COST & $\begin{array}{l}\text { a shop price plus general production } \\
\text { expenses }\end{array}$ \\
\hline Selling and marketing expenses & proportionate to a manufacturing cost \\
\hline TOTAL COST & $\begin{array}{l}\text { a manufacturing cost plus selling and } \\
\text { marketing expenses }\end{array}$ \\
\hline
\end{tabular}

Thus, the prime cost of a product item is a summarizing indicator of intensification and effectiveness of resource use and consumption and accumulates expenses on production and sale of a product item according to the set calculation elements. Figure 1 represents several types of calculation. 


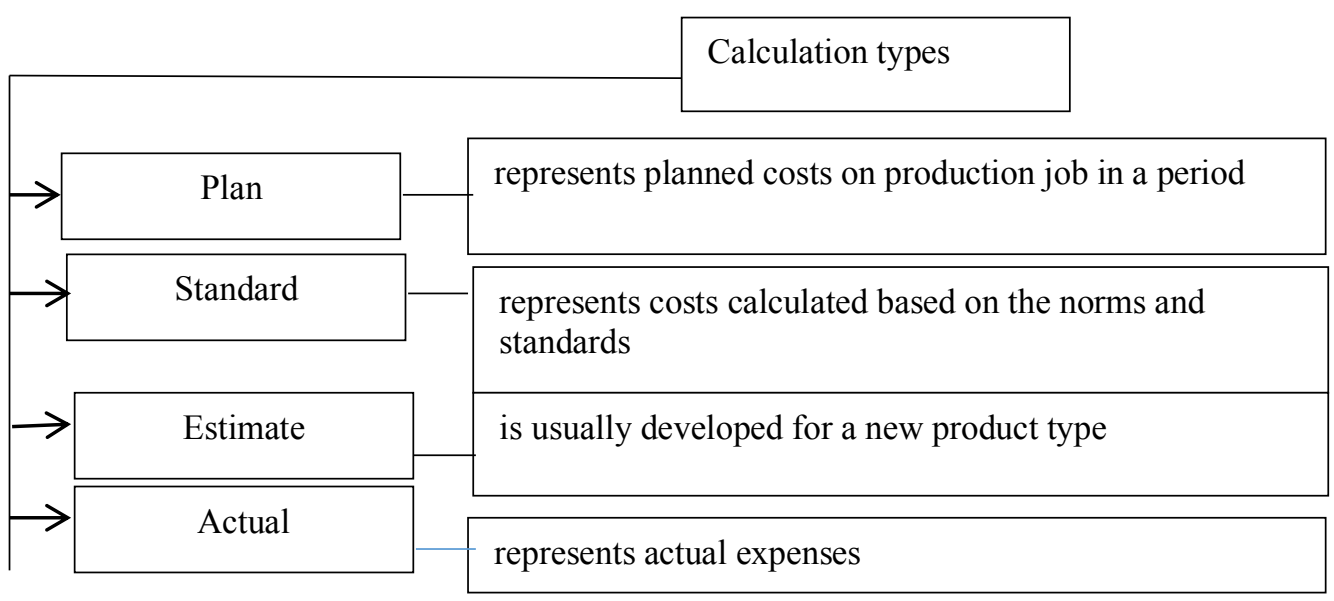

Fig. 1. Calculation types

The composition of expenses included into the prime cost of products, works, services is determined by the effective legislation (the Tax Code of the RF) and regulatory legal acts of ministries and agencies. The document which regulates the prime cost formation in the forestry sector is The industry-specific composition of expenses included into the prime cost of products at enterprises of the forest industry complex (approved by the Ministry of Economy of the RF on October 19, 1994) (as amended on December 26, 2002) (with Guidance (Instructions) on planning, accounting and calculating the prime cost of products in the forest industry complex approved by the Ministry of Economy of the RF on July 16, 1999). This document gives the composition and classification of the expenses included into the prime cost of manufacturing products of the core operations (timber harvesting, woodworking, pulp-and-paper and wood chemical industries) and auxiliary processes (repair, energy, transport departments).

We can consider some possible variants of determination of the prime cost of harvesting $1 \mathrm{~m}^{3}$ of timber in the conditions of the Republic of Mari El. For the purposes of calculation flexibility we use the following documents:

- Guidance on formation of prices for manufactured goods, performed works and services rendered by organizations operated by the Federal Forestry Agency on a fee-basis and initial (start) prices for forestry works and services purchased for the government needs (approved by the Federal Forestry Agency, Decree No.8 of January 31, 2005) [1];

- Norms for consumption of fuel and lubricant materials used for mechanized works performed in the forestry sector (approved by the Federal Forestry Service of the RF, Decree No.180 of September 13, 1999) [2];

- Guidelines for standard rates of production, standard time of cleaning cuttings in the plain environment (approved by the Federal Forestry Service of the RF, Decree No.148 of July 15,1999$)$ [3].

- Standard rates of production (time) and prices for preliminary, auxiliary and general labor works at the timber cutting areas (approved by Resolution of the State Committee for Labor of the USSR and the Secretariat of the All-Russian Central Trade Union Council No. 164/9-35 of March 29, 1988);

- Methodology for determination of contractual prices for forestry products (works, services) (developed by the All-Russian Institute of Continuous Education in Forestry, Pushkino, 2004) [4].

The flow chart of the manufacturing process is as follows: tree felling, limbing. An instrument used is a Husqvarna-365 motor saw. The composition and classification of the 
staff include a Grade 6 tree feller, a Grade 4 forest laborer, a Grade 4 branch cutter. An average stem volume is $0.35 \mathrm{~m}^{3}$. The work scope is presented in Table 3 .

Table 3. Work scope, $\mathrm{m}^{3}$.

\begin{tabular}{|c|c|c|}
\hline $\begin{array}{c}\text { Timber assortment } \\
\text { category }\end{array}$ & Species & Work scope, $\mathbf{~ m}^{\mathbf{3}}$ \\
\hline & & 592 \\
\hline large & coniferous & 427 \\
\hline middle & soft-wooded broadleaved & 2392 \\
\hline & coniferous & 367 \\
\hline small & soft-wooded broadleaved & 576 \\
\hline & coniferous & 16 \\
\hline firewood & soft-wooded broadleaved & 1546 \\
\hline & coniferous & 122 \\
\hline & hard-wooded broadleaved & 2270 \\
\hline & soft-wooded broadleaved & 8308 \\
\hline
\end{tabular}

The calculations are based on The industry-specific composition of expenses included into the prime cost of products at enterprises of the forest industry complex. In Table 4 we can give four variants of the prime cost calculations depending on the method of determination of expenses on equipment maintenance and distribution of an leasing fee.

Table 4. Variants of cost calculations for harvesting $1 \mathrm{~m}^{3}$.

\begin{tabular}{|c|c|c|}
\hline Variant & $\begin{array}{c}\text { Equipment maintenance } \\
\text { expenses }\end{array}$ & Leasing fee \\
\hline Variant 1 & $\begin{array}{c}\text { expenses on routine } \\
\text { maintenance or repair are } \\
\text { assumed as } 50 \% \text { of a } \\
\text { depreciation charge or } \\
\text { equipment wearing per } 1 \\
\text { machine-shift } \\
\end{array}$ & $\begin{array}{l}\text { distributed to the total } \\
\text { felling volume irrespective } \\
\text { to a timber assortment } \\
\text { category (a constant value } \\
\left.\text { per } 1 \mathrm{~m}^{3}\right)\end{array}$ \\
\hline Variant 2 & $\begin{array}{c}\text { expenses on routine } \\
\text { maintenance or repair are } \\
\text { assumed according to relevant } \\
\text { standards depending on the } \\
\text { machine system applied }\end{array}$ & $\begin{array}{l}\text { distributed due to timber } \\
\text { assortment }\end{array}$ \\
\hline Variant 3 & $\begin{array}{c}\text { expenses on routine } \\
\text { maintenance or repair are } \\
\text { assumed as } 50 \% \text { of a } \\
\text { depreciation charge or } \\
\text { equipment wearing per } 1 \\
\text { machine-shift }\end{array}$ & $\begin{array}{c}\text { distributed due to timber } \\
\text { assortment }\end{array}$ \\
\hline Variant 4 & $\begin{array}{c}\text { expenses on routine } \\
\text { maintenance or repair are } \\
\text { assumed according to relevant } \\
\text { standards depending on the } \\
\text { machine system applied }\end{array}$ & $\begin{array}{l}\text { distributed to the total } \\
\text { felling volume irrespective } \\
\text { to a timber assortment } \\
\text { category (a constant value } \\
\left.\text { per } 1 \mathrm{~m}^{3}\right)\end{array}$ \\
\hline
\end{tabular}




\section{Conclusion}

The calculation results are shown in Table 5.

Table 5. Prime cost calculation for harvesting $1 \mathrm{~m}^{3}$ of timber.

\begin{tabular}{|c|c|c|c|c|}
\hline Species & Timber assortment category & $\begin{array}{c}\text { Felling } \\
\text { volume, } \\
\text { m }^{3}\end{array}$ & $\begin{array}{c}\text { Prime cost } \\
\text { of } \\
\text { harvesting } 1 \\
\text { m }^{3 \cdot} \text { Rub. }\end{array}$ & $\begin{array}{c}\text { Total costs, } \\
\text { thousand } \\
\text { Rubles }\end{array}$ \\
\hline \multicolumn{5}{|l|}{ Variant 1: } \\
\hline \multirow[t]{2}{*}{ large } & coniferous & 592 & 524.43 & 310.46 \\
\hline & soft-wooded broadleaved & 427 & 480.55 & 223.95 \\
\hline \multirow[t]{2}{*}{ middle } & coniferous & 2,392 & 524.44 & $1,254.46$ \\
\hline & soft-wooded broadleaved & 367 & 476.12 & 192.48 \\
\hline \multirow[t]{2}{*}{ small } & coniferous & 576 & 440.49 & 253.72 \\
\hline & soft-wooded broadleaved & 16 & 523.86 & 27.42 \\
\hline \multirow[t]{3}{*}{ firewood } & coniferous & 1,546 & 310.81 & 480.50 \\
\hline & hard-wooded broadleaved & 122 & 496.54 & 60.58 \\
\hline & soft-wooded broadleaved & 2,270 & 367.51 & 834.26 \\
\hline \multicolumn{5}{|l|}{ Variant 2: } \\
\hline \multirow[t]{2}{*}{ large } & coniferous & 592 & 769.76 & 455.70 \\
\hline & soft-wooded broadleaved & 427 & 535.16 & 228.51 \\
\hline \multirow[t]{2}{*}{ middle } & coniferous & 2,392 & 655.70 & $1,568.44$ \\
\hline & soft-wooded broadleaved & 367 & 505.29 & 185.44 \\
\hline \multirow[t]{2}{*}{ small } & coniferous & 576 & 407.22 & 234.56 \\
\hline & soft-wooded broadleaved & 16 & 448.46 & 7.18 \\
\hline \multirow[t]{3}{*}{ firewood } & coniferous & 1,546 & 187.33 & 289.61 \\
\hline & hard-wooded broadleaved & 122 & 402.30 & 49.08 \\
\hline & soft-wooded broadleaved & 2,270 & 240.68 & 546.34 \\
\hline \multicolumn{5}{|l|}{ Variant 3: } \\
\hline \multirow[t]{2}{*}{ large } & coniferous & 592 & 776.57 & 459.73 \\
\hline & soft-wooded broadleaved & 427 & 498.08 & 212.68 \\
\hline \multirow[t]{2}{*}{ middle } & coniferous & 2,392 & 662.51 & $1,584.72$ \\
\hline & soft-wooded broadleaved & 367 & 463.78 & 170.21 \\
\hline \multirow[t]{2}{*}{ small } & coniferous & 576 & 415.91 & 239.57 \\
\hline & soft-wooded broadleaved & 16 & 454.68 & 7.27 \\
\hline \multirow[t]{3}{*}{ firewood } & coniferous & 1,546 & 194.48 & 300.66 \\
\hline & hard-wooded broadleaved & 122 & 412.86 & 50.37 \\
\hline & soft-wooded broadleaved & 2,270 & 247.48 & 561.78 \\
\hline \multicolumn{5}{|l|}{ Variant 4: } \\
\hline \multirow[t]{2}{*}{ large } & coniferous & 592 & 517.63 & 306.44 \\
\hline & soft-wooded broadleaved & 427 & 455.23 & 194.38 \\
\hline \multirow[t]{2}{*}{ middle } & coniferous & 2,392 & 418.54 & $1,001.15$ \\
\hline & soft-wooded broadleaved & 367 & 466.27 & 171.12 \\
\hline \multirow[t]{2}{*}{ small } & coniferous & 576 & 378.24 & 217.86 \\
\hline & soft-wooded broadleaved & 16 & 401.27 & 6.42 \\
\hline \multirow[t]{3}{*}{ firewood } & coniferous & 1,546 & 303.65 & 469.45 \\
\hline & hard-wooded broadleaved & 122 & 485.98 & 59.29 \\
\hline & soft-wooded broadleaved & 2,270 & 360.71 & 818.82 \\
\hline
\end{tabular}


As can be seen from the above, prime cost formation by different methods may lead to different results.

To assess wood resources at the regional level we have to take into account the following specific features [5]:

1. The wood resources are spatially located in the territory of a region, so this makes their characteristics be regional. This type of natural resources is a large-scale in terms of space and time regional capital which can give a constant income if the right methods of forest use and regeneration are used. At the regional level, availability of such large-scale in terms of the territory and time sources of material wealth as the forest stands of a region generally differs in values from a region to a region.

2. Due to its natural and climatic environment, each region is characterized by its own quality range of the wood resources available in the territory of this region. The natural productivity of different species is in direct relationship to the favorable for a certain tree species conditions of the climate, relief, and soil which have their regional characteristics.

3. Quality and allocation of the wood resources within a region make an impact on management decisions concerning the use of wood resources of a region.

4. A regional business sector engaged in harvesting and processing the timber reserves orientates at the regional market prices for forest products and on the availability in the region of manufacturing facilities for processing raw materials into final products, convenient transport routes, closeness and capacity of markets for selling both raw materials and final forest products.

All the above mentioned specific features of the wood resources should be taken into account during the assessment process as they influence the prime cost and price of the wood resources.

\section{References}

1. Methodological recommendations on the formation of prices for manufactured goods, work performed and services provided by organizations under the jurisdiction of the Federal Forestry Agency, on a paid basis, and initial (starting) prices for forestry works and services purchased for state needs: approved Federal Forestry Agency: Order No. 8 dated January 31, 2005 (Moscow, 2005)

2. Rates of consumption of fuels and lubricants for mechanized work performed in forestry: approved. Federal Forestry Service of the Russian Federation: Order No. 180 of 13.09.1999 (Moscow, 1999)

3. Typical production rates, time rates for thinning forest maintenance in flat conditions: approved. Federal Forestry Service. Order No. 148 dated July 15, 1999.

4. Methodical recommendations (instructions) for planning, accounting and calculating the cost of production of the timber industry complex (Extract): approved. Ministry of Industry and Science of the Russian Federation December 26, 2004 (Moscow, 2004)

5. T.G. Kolesnikova, Payments for forest resources as a factor in the socio-economic development of forestry: on the example of the Republic of Mari El: abstract of dis. .Candidate of Economic Sciences: 08.00.05, (Yoshkar-Ola, 2002) 